\title{
反對量子力輩中的唯心主義
}

\section{M. Э．奥密里揚諾夫斯基}

最近幾年來, 由於黨的倡導, 在我們國家裏進 行的關於哲學、生物學、生理學、語言學筞問題

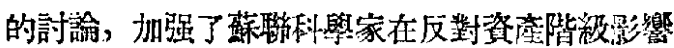

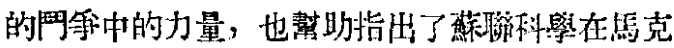

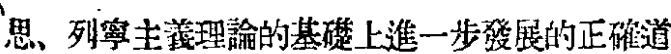
路。

斯大林同志的天才著作“熙克思主義與 語言 學問題”, 以新的思想武器武裝了蕉聯科學家以及 其他各國的進步科學家隶和馬克思主義的一㽖敵

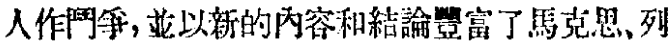
蜜主義及其哲學。

一切科學之基礎的馬克思、列蜜主義哲學，在 研究非生物自然界的部門, 在物理學部門中, 也同

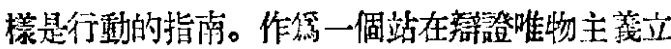
場上的科學工作者，就不僅必須一般地承詔党 思，列䀂主䔐哲學原理，而且還必須盖於應用這種 哲學來解决自己那門科學抅一切大大小小的問 題。

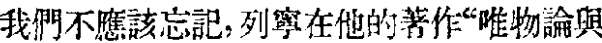
枚驗批制論”中所天寺分析的關於唯物主義與唯 心主義在近代物理學中的鬥等，在我們造㨐侍代 震是一次又一次地加强了，而且謷來了新的特徽 和內容。日丹諾头柌志在1947年的晢學討論畣中，

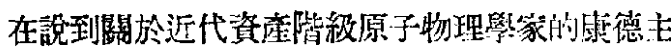

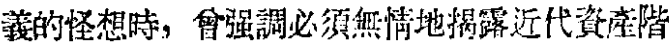
級科學用來供給值侣主蓄的那種新的論㫮。

如所週知，海森堡和波爾這些外國物理學界 所讀哥本哈根學派的領袖，不但爷持唯心主義，而 且以他們的非些学常是会糊的以及公然是唯心主 清的䜿於原子物理的原理公式，以他們所謂测不 準閣係的諭述以及他們的那些主觀主義的物理學

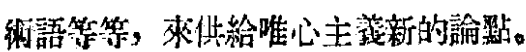

所以我們必須在禞證唯物主载的基磷,上仔細
分析量子力學的富䮲基礎及其原则原理的根摭,

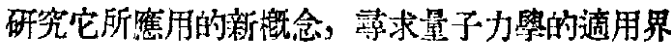
限(超過這個界限它就不能正碓地反胦自然, 而得

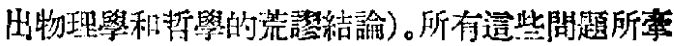
涉的不正是物理學，同時也涉及哲學，而在晢學部 門，正如列蜜所数導我們的，不能相信一個資産 階般坆投的一句話。

那然，在量子力學的哲學基磷造個問題上，一 個該證唯物主義者應該採取怎樣的立場呢?

在捉出齔量子力學的論述時，他應該以承認

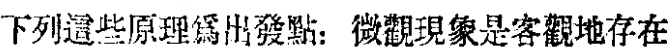
着的; 窄觀物體和微觀物锠是連動的物筫的統一 鍊條的各個懪節，但同時文是互相區别着的; 在微 觀現像和芸觀現象之間证不存在形而上學的䠐 壁; 而微觀物軆的所标性筫可以這樣或那樣表現

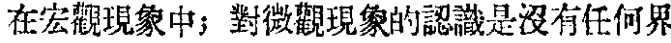
限的。

某個作者在論述量子力學侍可以承認造些唯 物主義的原理，但這亚不是锣他就能够徹底唯物 地解决在自己面前所提列的任衫。在一般地承認 某一思想和在科學研究的余一具繥情况中望現证 創造地應用這思想，其關的距敨是不小的。

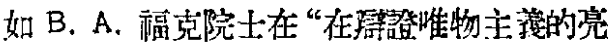
光下的物理基本定律”這篇論文赛，討諭到波爾和 要因斯坦的關於波動㖤數的物理意意的論獤時， 只是批刵地分析了波爾關於“物理的真實”問題的

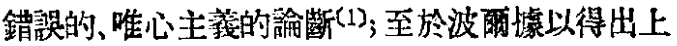

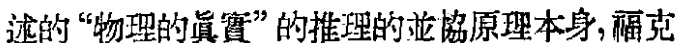

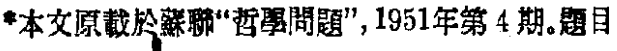

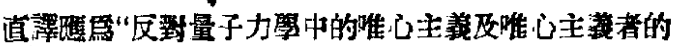

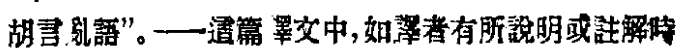

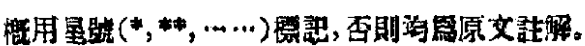




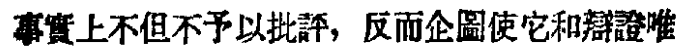

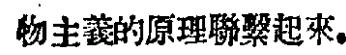

A. $\Phi$. 約非院士在“現代物理的基本觀念”一 書中, 批評了海森堡、愛丁頓以及其他資產階級 科學家們的唯心見解, 同時又認旊和蓝協原理聮 繁的是些完全正確的、只是生疏的，但可以“在創 造的馬克思主萑方法的葓礎上”去研究的物理觀 念。約非竞把關於量子力學的造樣完全不正確的

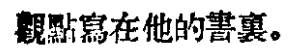

現在遭篇諭文的任移是要研究第堅持唯物主

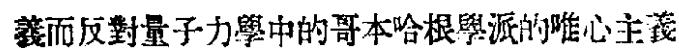
的閏孚，這鬥孚是以落聯科學家第首的進步科學 家們正在進行的.

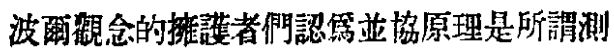
不準原理的繼續墢展，而测不淮原理本身就是波 霜學派所錯謂地提高篇原理的測不淮關係。如果 從數學方面來形式地看, 造個留係就是指坐標 $x$ 的测不準度 $\Delta x$ 愈小则動量 $p$ 的测不集度 $\Delta p$ 忿大, 反之亦然 $(\Delta x \Delta p \sim h$ ，逼裹 $h$ 是蒲财克常數)。

從形式上推論, 測不淮關係可以由三型方法 得到: (1)根㨜經典的波動理諭和德・布洛意假 定，以粒子動量和波長相比推導出隶(例如，這個 結諭見於 3. B. 史波里斯基的“原子物理學”一書 的卷一, 1949年版); (2)從所謂波動函夥性質— 量子力學基本概念得出 (例如, A. U. 布洛欣来夫 在 “量子力學基礎”一書中就是這㨾做的); (3) 由所謂對微觀物體的假想實驗(Мыслөнный әкспор-

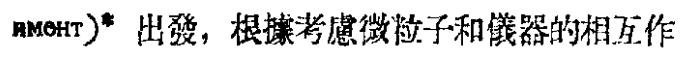
用的推理中得來（哥本哈根學派的代表通常就是 造樣做的)。然而, 我們必須注意, 在一般量子力學 課本裹, 幾乎任何萻者在說朋测不準關倸這调問 题時, 總是把三種方法錯綜起来, 而同時又必定是 倔重迹種或那種方法。

對於得出测不潐關係的方法的哲祭分析，在 我阴逼個諭題中特别重要。那就是因经哥本哈根

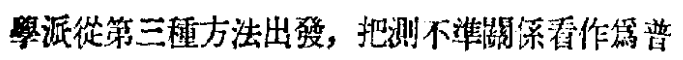
这性原理，並且演展成並協觀念，不正確地把波動

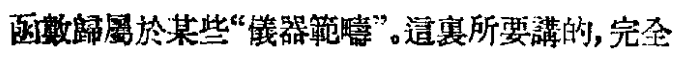
不是說, 一個站在唯物論立場的物理學家必須摒

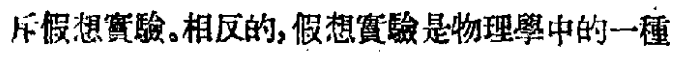
理䜽研究方法, 道種方法在物理理諭的一定範園
内常被應用，並從而得出對於理諭很重要的結果。

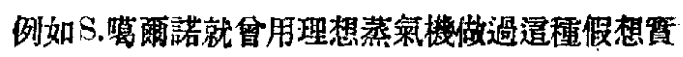
驗, 而獲得了大家所知道的熱力學上的重要原理,

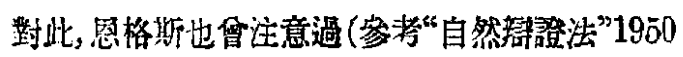
俄文版，181頁)。但由假想筫驗所得出來的結詇，

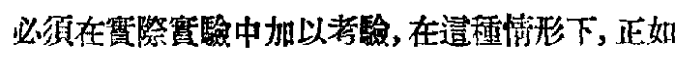
在一切理論研究工作中一楛, 貫際䁈驗是造些結

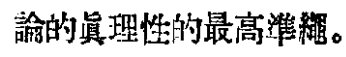

然而哥本哈根學派用在量子力學中的假想實 驗, 却和上面所說的假想實驗不同。如果謃後者是

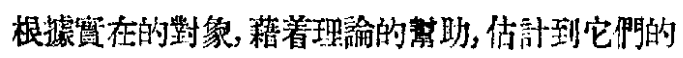

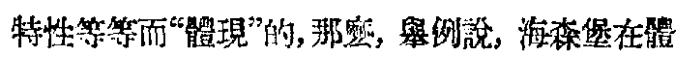

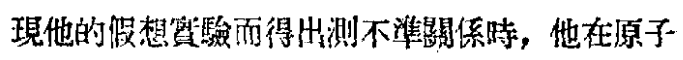

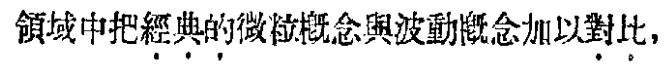

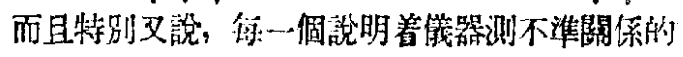

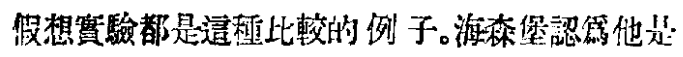

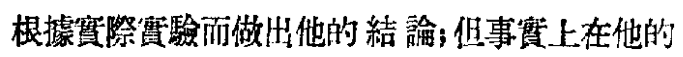

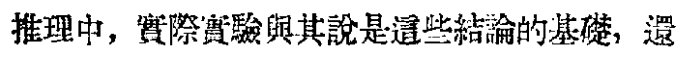
不如說是作殸造些結諭的訜明。海森堡在整個量 子力學中提出一個思想，就是: 由於微觀物繥和宏 觀㵶器之間你在根标上不可控制的相互作用，因

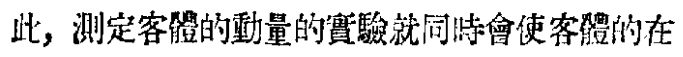
以前是可以测定的坐標變笏测不淮, 而海森稚認 第, 這種根本上的不可控制性是和测不淮關係住 機地聯粼着的, 於是此關係就得到了特殊的“哥本 哈根察派的”本筫上是唯心主堂的解釋。知名的外 國物理學家包里在討諭了根本上不可控制们相互 作用㭙, 强調說, “當一個經典概念的運䏳排斥号 一個經典觀念，我們根壉波爾的說法，就称這雨個 概念第亚饬烛的; 例如, 微粒于的坐摽和動量就是 這樣的。”(

波爾也說到逭點。他在提出自己對湖不準關 係的源理上的解釋時，他指出: “在量子現缘範四 內, 我們不能潐確計算客體教测量䉝器的纡作用,

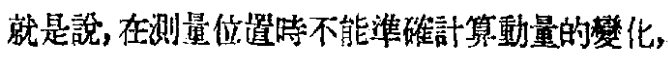

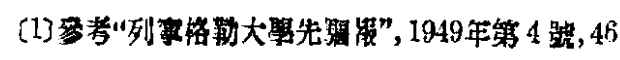
而。

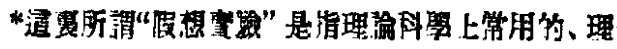

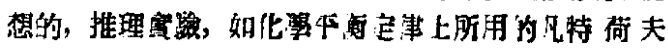

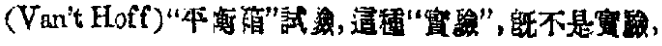

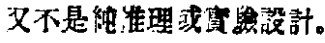
8 月版。 
在测量動量時也不能做確計算位移"(1)。正是因篇 逼堌線故，波爾說，量子力學的特點在於把動量和

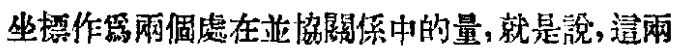
個量的其中一㑬被测量得越準確，则同時另一個 就越不能被测量得準確。這也就是波爾的並泇觀 念的基本酒義。

於是，B. A.福克馀: “並協原理是表示被测 量的客體和测量儀器的特性, 即物筫的特性的方 程式”。他企圖强調似乎並協原理和唯物諭论不是 分枝的。

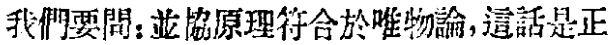
確的嗎?

這储問題由蔡聯科學家加以分析研究並解决

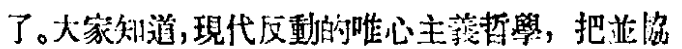

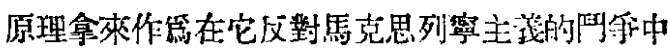
的一種武器, 把它當作“科學”的新論㨜。立情原理 導出如電子的“自由意志”之類的唯心的論斷，尊 出臭名昭新的二者摆一說: 或者是汥有因果律的 對洔空的說明，或者是在洔空之外的因果律等管。 在道佔原理上证建立起饪部“並協哲學”，及其在 “生物學的”和“社會”方而的種程結論(2),這程“哲

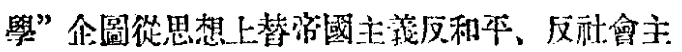
㼁、反民主的醜惡罪行找根㨜。不止約賞、赖字巴 赫、叛落克，就說是哲學家們，他們所做的㯙業就

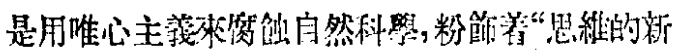
方式”，而且物理學家波爾也把自己苦作的不少篇 輻用來把“滥济原理”應用到心理現象、生、物現象、

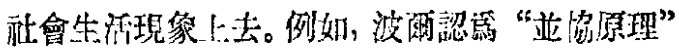
“特别是在關於研究和比較人類文化的問題上”很

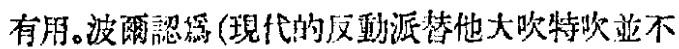
是偶然的）或者是統一的，一切是族的文化（常然

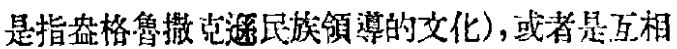
競争的許多民族的文化，問題就是這楴的 ${ }^{(3)}$ 。所以 “並協折學”就是晹站象心地篇資育階級的世界主

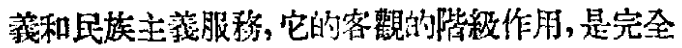

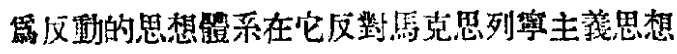
體系鬥爭中服務，它是效忠於美帝國主蕂的。

囱憾的是，我們的某些進行反對科學中唯心

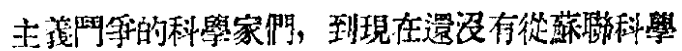
向哥本哈根學派的反動思想所作的批制中，做出 所有必要的結䍱。例如 B.A.福克院士在本質上並 不把测不準關保和波酸的並協原理相區別(4)，而
認篇量子力學(連同它的波動函数) 的特徽在於: 在量子力學中“我們已不應當简單地詮客喵，而

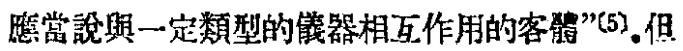
是, “客體與儀器同格”、“根本上不可控制性”、以 及其他類似的論斷，却是替唯心主義的 “並協觀 念”及其電了的“自由意志”等等胡說提供了“物理 學上的”基礎。這一點, 我們只要研究测不準關係

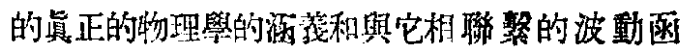
数, 就可以筷清楚的。

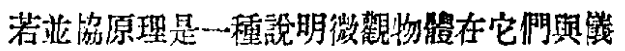

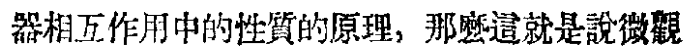

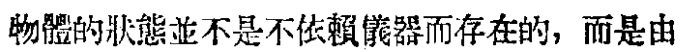

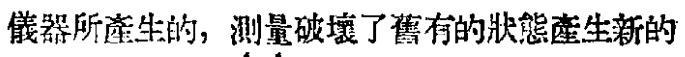
狀態等等。

在 Л. 㓢道和 E. 里甫西茨的“量子力學”新本 中(然一), 會經指出: “量子力學中的测量過程, 具 有一種重要的特點, 它總是影響着被测量的電子, 而這程影響在有一定的測量準確性時是根本不可 能使之成第任意小。测量得越潐確, 則它所引起的 影響就越大…...”(第 13 互)。

3. B. 史波里斯基在他的“原子物理”一書中寫 道: “……量子理論計算……賽際存在的, 我們稳 之第“微䊉:子”的客體與另一些賽際存在的宏觀物

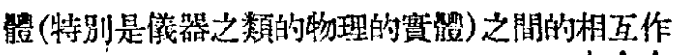
用。”(見 427 页, 着重整是我加的—M.奧.)。

在包里的有名的著作“波偊力學一般原理“中 地記截着同樣的觀念，䧟裹特品强調“测量使被試 駿的體系事入一储新奘態”(第17页)。

類似的例子很多, 不滕枚暴。遭些例子可以說 是有泹有㨜地證明着, 在許多物理學家看來, 並協

[1]“物理科學的淮展”,14然，第4期, 1986年, 452頁。

B. A.福克及其他: 量子力掔問題論臹。“在馬克思主 義的旗阵下”，第1期(1908年)，152頁。

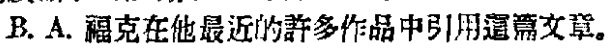

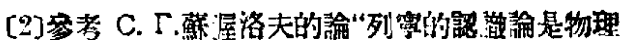

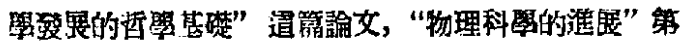
39 第 1 期, 1949 年。

〔3]点考波爾在 “Dislectica” 雜誌, $7 / 6,2,3 / 4,(1948$ 年)中發表的頱文。

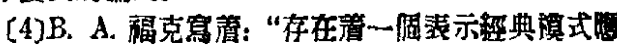

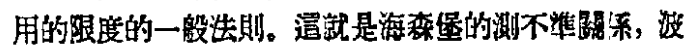

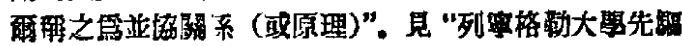
侥”1949年,第 4 號，第39䫀。

[5]同上, 第43頁。 
原理與量子力學是一而二,二而一的東西。

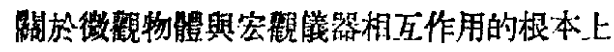
不可控制性造倜原理以及關於在量子力學中客鳞 與...定形式的宏觀儀器原則上同格, 因而應用一 種儀器就排除同時應用另一㪙儀器的說法, 遭就

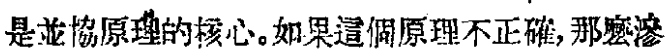
入波爾的“泣協理論”裹的所有其他原理也都是不 正確的。

首先前拁原理的䋇陷在於，如其說它着重提 出量子力學所研究的原子客體的特點，還不如镪

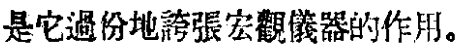

誠然, 浔有宏觀儀器，人就不能知道原子領

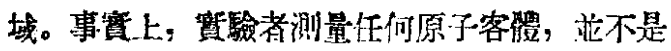
一切都道接依靠宏觀儀器(例如, 中子的性質是根 據它和質子磁摬的結果來判斷的)。可是由儀路所

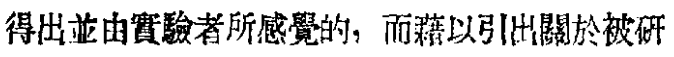

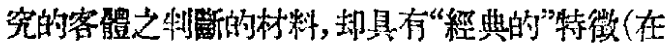

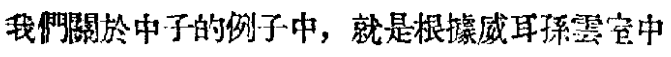

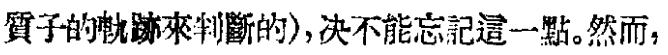

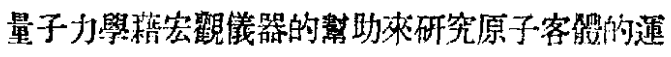
動，這種情形，絕溸不㮣當說似乎原子客體的性 質- 一本質的部分或非本質的部分無關緊要, 事 情並不依此而改變一一是由儀器所黄生或慗造出 來的。原子客體以及它們的性筫不传赖人和 儀器 而存在, 踓然它們可能而且、買際上也碓是和儀器 的構成部分相泣作用。這些客體证且是不低賴儀 器 (不是在與䉝器的相分作用中) 而的量子理論反 胦出來的。

我們不能像 B. A.福克院士在上述那篇諭文

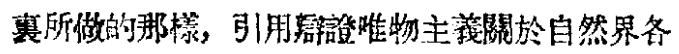

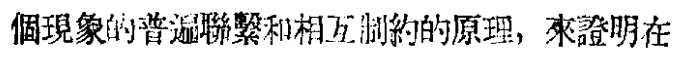
量子与學中我狮必須說與儀器相互作用的客體, 面不是简單地只說客體。讙證唯物主義關於各個 現象的聯薮的原理是說, 假如把一種現像從產生

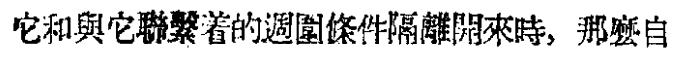
然界就涩有一種現像是可以㙞解的。正如 B. A. 福 克所承認的, 微憼物體茹不是由儀器所產生, 也不 是和它有機地聯粼省的。儀器這一個物理實體, 和 被研究的客體相互作用前且改變它, 但是在關於

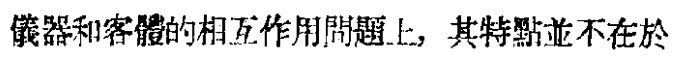

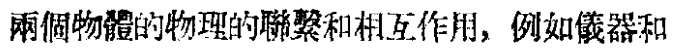
客䯘，而是在於藉助於一储物體 (在寈襄就是作篇
儀器而出現）來研究與它起着相互作用的另一倜

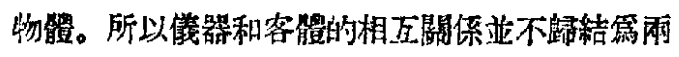

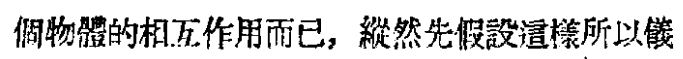

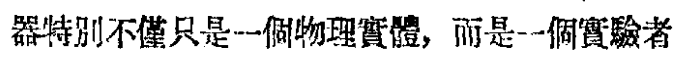
放在他自己和被破究的物體或現象之間用以認識

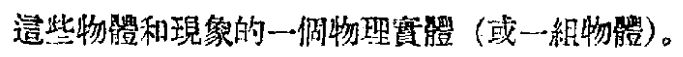
實驗者利用鹪器這一個物䯏的物理性質, 從這個

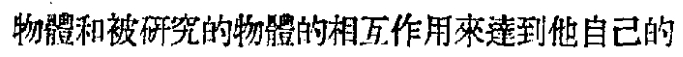

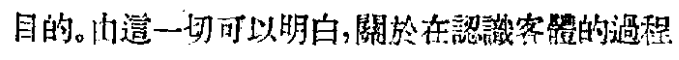

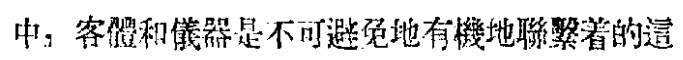
一個諭斷, 事·霓上正好是適合了唯物主義的敵人

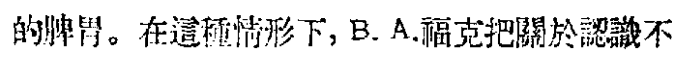
低賴於儀器而存在的現像的間題, 和關於拿顧一

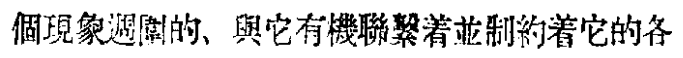

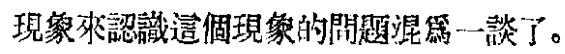

A.Ф. 䄪非院士也犯了類似的錯譟。他肯定只

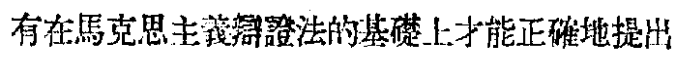
關於我們籍以認識外在世界的義器興造個外界的 現象相互作用的問題，同時他却又扯到出名的、本 質上是不可知馀的、哥本哈根學派的原理: “在我 們的測量的準確程度上存在着一個極限, 這是任 何一個賽際的笔器所不能踰越的, 此限度依被研

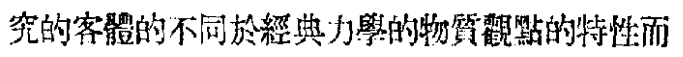
定”。(1)

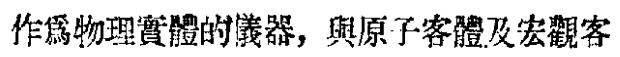
鰽都起相互作用。物理學家根據内儀器記錄下的 客䯏和儀器相互作用的觀繁結果来判斷客傮。在

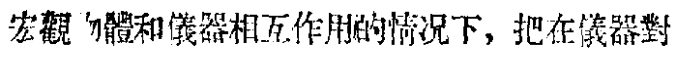

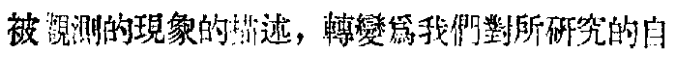

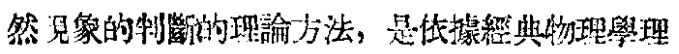

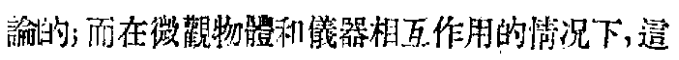
犁方法則依據量子理論和它的波動函數, 可是, 其

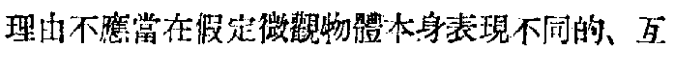
相排斥的物理佟件（由儀器所造成的）上面去找 (在一種條件下, 微觀物體表現和帶有動量的宏觀 粒子于相當, 在另一種棨件下, 和有一定坐標的宏觀 粒子相當)。這裹的理由完全是另一回事, 理由在 於微觀物體和空觀物體不同, 它具有真正的不可 分的微粒一場，或徵柆一波的特性。量子力學在 它的真正內容中就是以這些特性暚前提的。要是

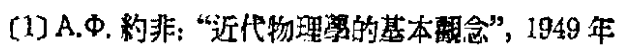
版, 第 146 貝。 


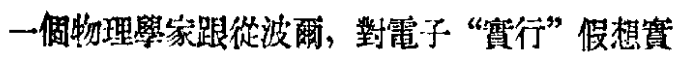

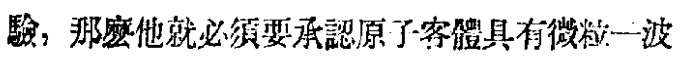

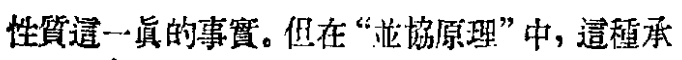
認並不是被當作新的物理觀念的根源, 而却是當 作一種拐杖, 被息名昭影的“根本上不可控制性” 諭調一次又一次地所依恣着。例如, 波西社他和愛 因斯㫜討論時, 很樂意引簦電了的衍射作用, 從假

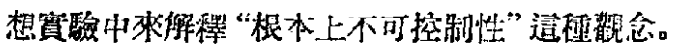

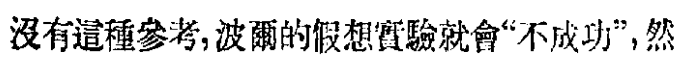
而笔子的衍射作用這個事實, 在波䨋的推埋中只 能作学是一㮔引證而已，别無其他(1)。

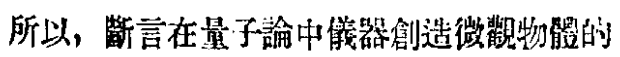

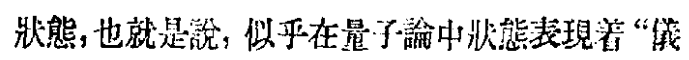

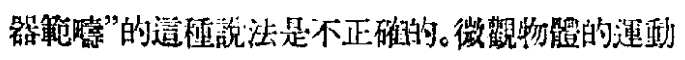
狀態不俈賴於人和测量籍器洑仔在着。原了客體

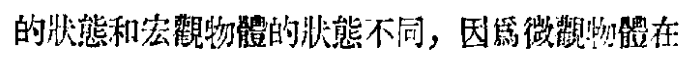

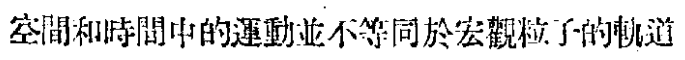

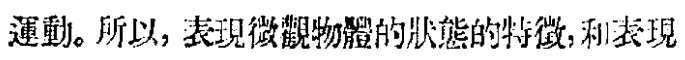

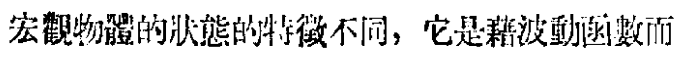

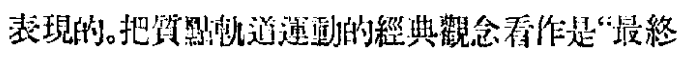

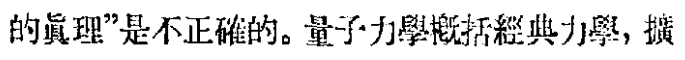

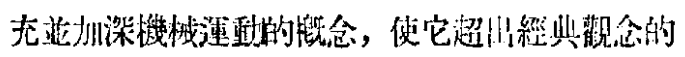

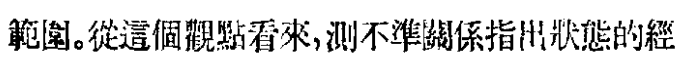

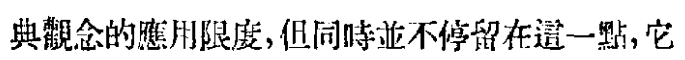
並且是㸝態的量子概念的特徽。 测量閣題。

在 Л. 期道和 E. 黑甫四茨的“量子力學”書中 說: “量子力學的测量包含着經典萑念客體與量子-

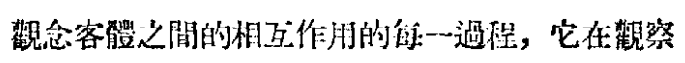

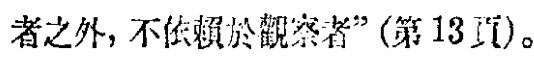

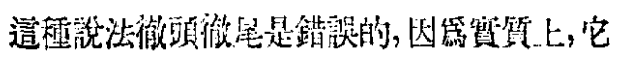

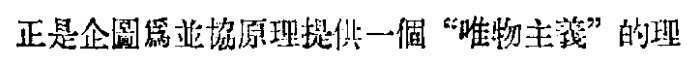

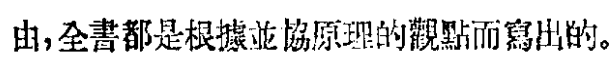

首先, 這㮔敦法的錯誤是: 它把测量看作篇物

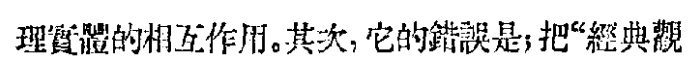
念客體和量子觀念客體間”的相互作用的特徽的 “量子力學的测量”混篇一談, 但這種测量却是和

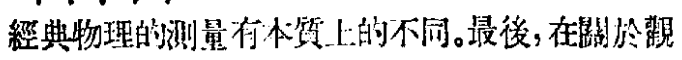

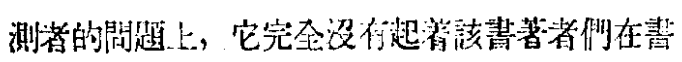

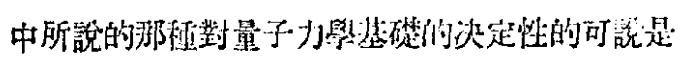

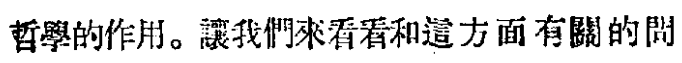

題。

如所遇知, 波爾學派是䍃微觀物體和宏觀敾 器間相互作用的“根本上上不可控别性” 而喭護。似 乎就從邆裏引以测不準關係, 引出微觀物短和宏 觀儀器原則同格的必要性管等, 根㟫哥本哈根學 派的意見，所有這些東西連同 “根本上不可控制 性”使量子力學不同於經典力學。

事颚—:問題完全不是這檺。我們可以引用一 個大家所熟知的，經典物理學的例子。假如我們要

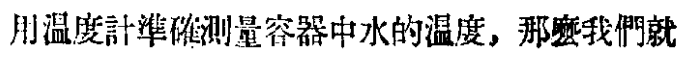
應當考虑到山於温度計的放入而使水的温度戀化 這一事賽。但是, 根㨜温度計的讀數, 引用繁現象 的琶馀, 我們就汀以推求出在温度計故淮以前水 的温度。在這一䧳上量子力學利經舆理諭有什㦄

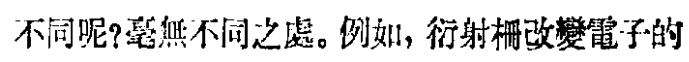
将態, 使它們轉化第一個䉼的系綜（新的狀態）,

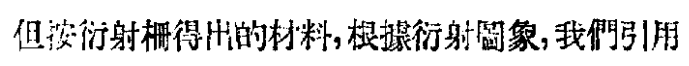

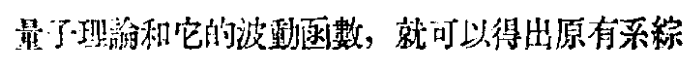
的判断。同超的本筫在於: 第一, 改變客䯏的不是 测量, 而是和测量聯獒着的物理過程。测量以進行

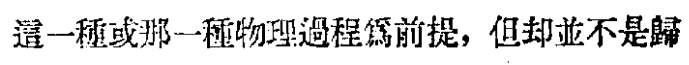
絬於這種過程, 那就是镜, 测量篇了逢成其目的, 除了利胢儀器的㵑數外, 還必須引用反胦了自然 的烧律性菂某理物理理論。量了力學中的測量正 如所偷全部物理學的测量一樣, 自始至終是一種

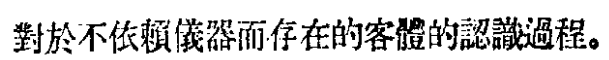

列蜜在置重指出测量的認識体質時竄道: “如 橗不把連續的間斷，不把生動的简化，粗化、分割

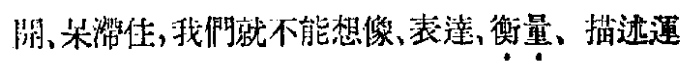
動。”[2]所以在說到量子力學中的测量以及一般的

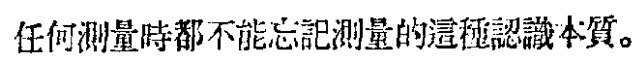

第二, 荒漻的“根本上不可控制性”是㗄了給

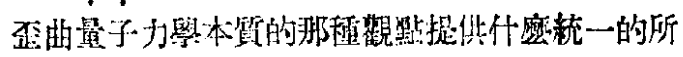

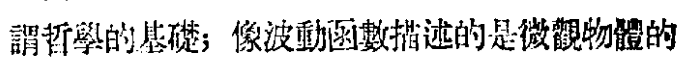

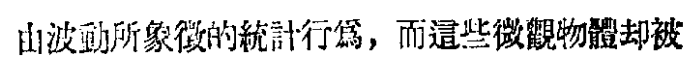

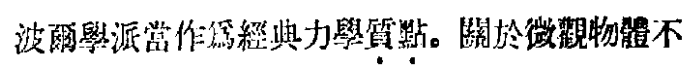

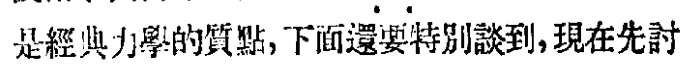
諭量子小學山地的鹳测者問题。

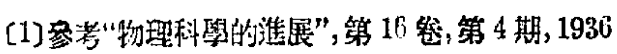
年, 第 449 頁。

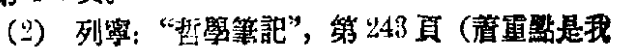

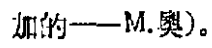


上面說過，觀察者主體在並協觀念望並不起 某些物理學家和哲學家所給它的排楚决尖性的 “哲學上的”作用。刀. 期道和 E. 里甫酒茨强詩在量

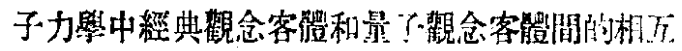
作用是在觀察者之外不依權他而進行的, 但造完

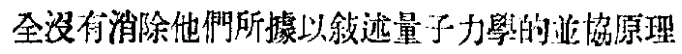

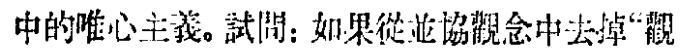
察者”, 而代以“勒影機”、“威耳係雲室”等等”，或總 而言之以儀器代柏“觀察者”, 那麼, 此觀念的唯心 主俄本質是否就改變了呢? 不, 並汥付改變, 這 可以從赖宁巴赫的著作中指出來。這位傅統的留

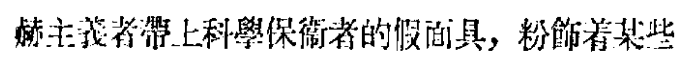

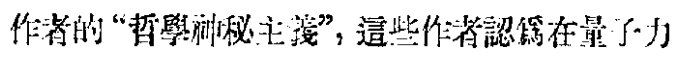

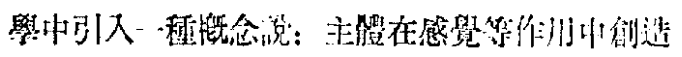

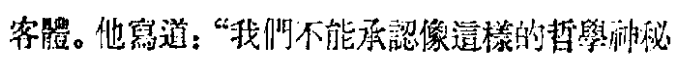
主義的任何諭調在量子力學中會有什䐴基礎。像 所有其他物理理論一䓇, 量子力學所做讪只是求

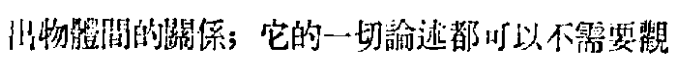
察者而作 $H_{4} \cdot \cdots \cdot$. 這意思就是, 可以用物理儀器, 例如光電管等: 来替代觀察省。”(1)

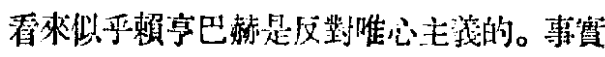
上，他踓然從量子力學中去掉觀察者，可是他的哲 學立場却一點也沼有變成唯物主蓄的。

如所週知，按波爾和海森保的意見，儀器所測 定的不是不依賴於它而存在的客繥，而是與儀登

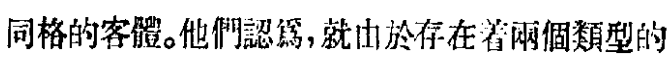
相互排斥的筙器; 所以對量了客體的测量必定改 變該客澧的少態。因此，根據哥本哈根學派的學

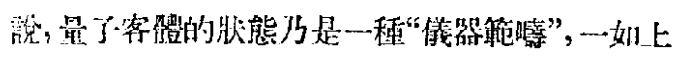

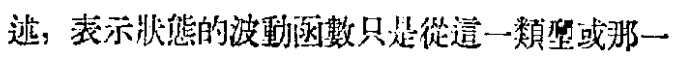

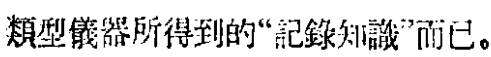

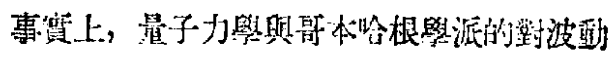
函數的主觀想法毫得共同之點。篇了明白遥件事,

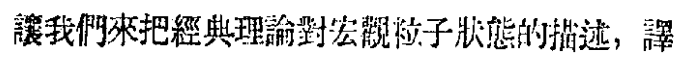

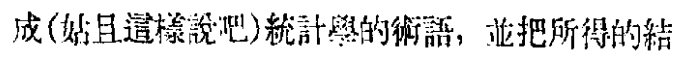

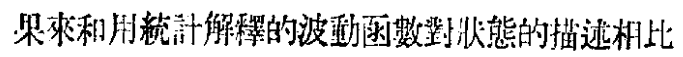
皎一下。

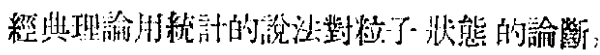

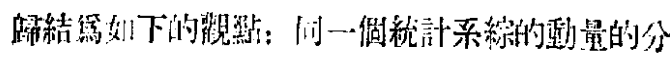

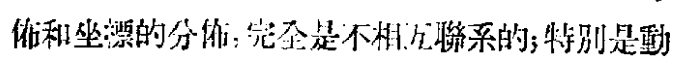

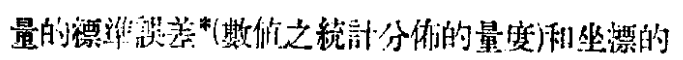

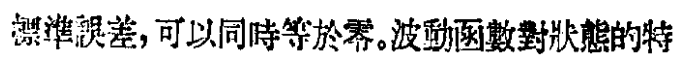
徽的統計的渵述则是: 同一個系綜的動量的分侑 和坐標的分㑜是彼此方相聯系的, 而且這楚聯系

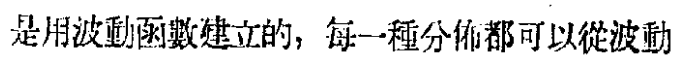

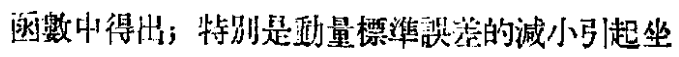
整標淮誤差的加大，反之亦然，這就是說，同一個

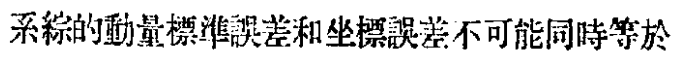
零。後者就是测下潐關係。從波動函數中來得出邆

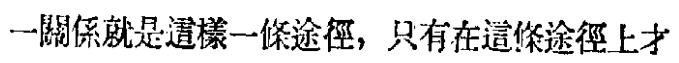
能尋找出這一關係的奋正內容。波爾學派却總是 以測量來對讎测不準關係。

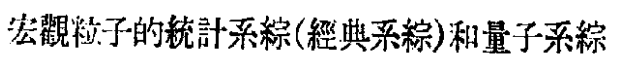
就是這㧼朴質上相互區别着的。

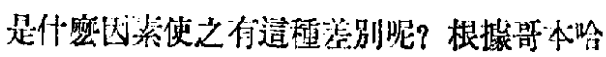
根學派的瀖法, 就是测量的過程必然對客䯏状態 造成不可估計的破壞，亦即，测量似乎破壤一個特 徽而座生一個新的特徽, 因此就使量子”客渭依這 一新的特徵而結合在統計系棕中。掺刉話说，汥仿 测量就浔有各種留性一一本筫上這就是哥本哈根 學派的唯心主㼁的見解。

事實上，經典系綜和量子系綜的不同乃是由 於組成它們的客體不同之故。微敬物體有別於宏 觀物體是在於微觀物體的固有的，不可分離地連 結着的微陪和波動的特性，因此軌道的概念就不 能適用於微觀物艋; 這程不同表現在微觀䌅計 (量 子系称) 和宏觀統計 (經典系棕)的不同。哥本哈

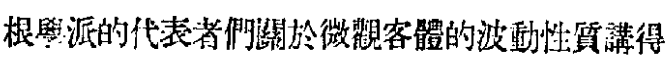
很多, 可是在具體的物理研究中, 照他們看來波動 只是汥侍真察性的抽象, 只是粒子的特殊的統計 行第的標誌而已。

必须全力强調, 電子的波動性質和它的微粒.

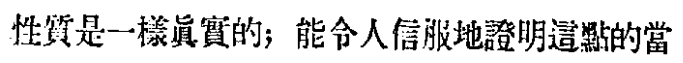
然不是罚本哈根學派的犌想貿媛, 而是實際的實 䲆。在造方面， C. H. 正維洛夫院士的光線在强度

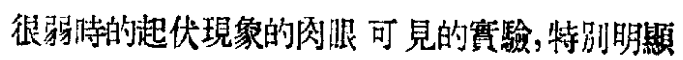
地表明量子客㺏的本質。誠然，一道光線不是一 注電子流, 但是在這種情形下, 問題不在於二者彼

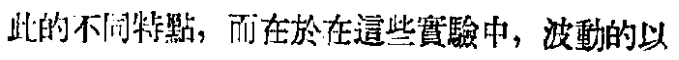

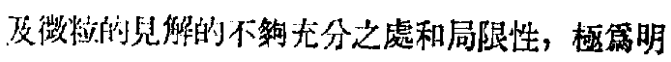

（1）赖亨巴赫: “量子力學的哲㬴”，1946版，1516 面。

*或稱偏差繁胡万根。 
顯地在眼前被揭示了出來。看來, 光在强度很弱 時座生一種干涉圖案, 但是與普涌强度的光線所 形成的干涉圖案相比較, 它却有這樣的一個特點, 就是, 在明帶的地方可以觀察到一些不規則的起 伏現象, 各自獨立發生於每一個明帶裏。換们話 說, 光波只是在和光子微粒的統一中存在着, 就 好像光子在似乎是統計的散漫中服從於波動規 律 ${ }^{(1)}$ 。同樣的事頯一一但已是通接關於䉓子的 一一在 Л. 畢别爾曼、H. 蘇式金和 B.法伯里坎特

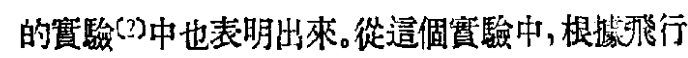
電子的行射, 推出這樣的一個結論: 各個䉓子同 時又是微粒又是波。一個電子涌過獄射系統產生 一個站點(電子直射的徑跡)，而不是行射圖案，所 以它苝不是波的構成。但是，若實驗侍間足够地 延長, 不規则分佑的昰點最後却會連接起來縕成 烆射圖案，由此可見，電子亚不是像桱典觀念的煜. 子那愫，只和衍射系統中的一個或少數原子相互 作用，而是和整個衍射系統相互作用，即電子是波 的構战。所以，䉓子是作签微䊉和波的某種不可分 的集合澧而通過衍射系統。

實在說來，每個研究量子性質的賽際的賽驗， 例如 A. 康普登的研究X射線散射頻率與散射角 的關係的著名的筫驗，根本不可能在經典物理概

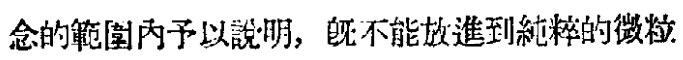
的解臎中去, 也不能用純粹的波動的解釋法。這 個問題在布洛欣朵夫的 “量子力學基礎”一書中 有所闌述, 但是它的重要的哲學方面, 却還不留 第某些蘇聯物理學家所明膫。像在 Э. B. 史波里斯 基的“原子物理”突一中竟提出這樣一種想法,認 筬不同的光學現象 (以及和電子運動相聯慗的現 象), 可以從波動的觀點來看, 也可以從微粒的觀 點來看, 而且還“證明”网種観點似乎是同等的

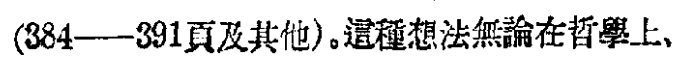
在物理學上都是不正確的。在哲學方面不正確, 是

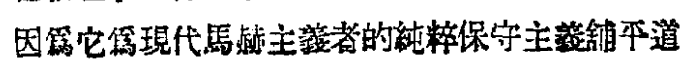
路(3)。在物理學方面的不正確，可以由衍射䅦的例

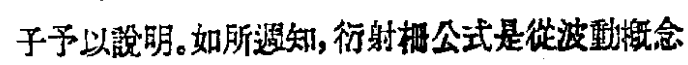
的基礎上得出來的。而 Э.B. 史波里斯基以震這 個公式也可以從微暗概念的基礎上得到，事實上 他是利用了量子概念(波爾的量子焂件、光子動量 方程计等等)。量子概念些不成黨微粒概念，像 Э. B. 史波里斯基實際上所做的那樣 把量子概念

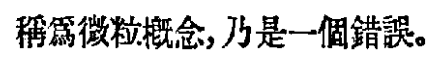

微觀物體的波一微粒性筫也說明量子力學的 物理量 (例如量子動量、量子坐標、量子能量)與經 典力學相當的物理量有新的不同的方面，正如 A. И. 布洛欤采夫、 Я. П. 切爾列荻基和 A. Д. 亞歷 II大洛夫所指出的。大家知道，經典力學的物理 量相當於數學的溥續數, 而量子物理數量则相當 於所謂線性自共䡉算符。線性算符反映所謂奘態 的叠加原理，塄一原理指明了波動函數的基本性

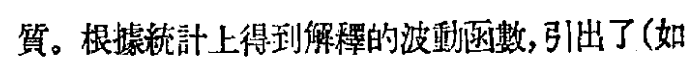

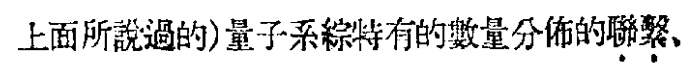

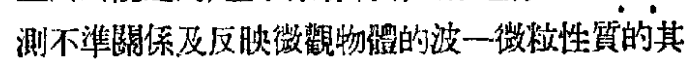
他統計原理。

從上面說的可以明白，測量篦器並不 “潐備

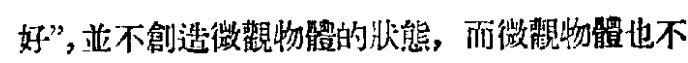
是像“敉典”粒子那棂服從統計運動法则的個別的

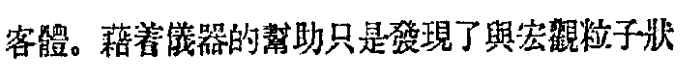

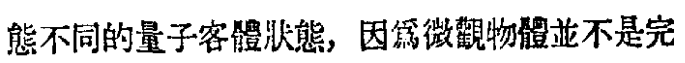
全像“經典”粒子按帎道僬行運動的。換句話說，

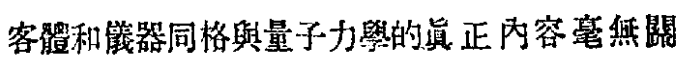
係。波爾一海森堡學派絕對化了“經典的”䊉子 概念, 以這一概念的不相稃的外衣裝飾了波動函 數。“根本上不可控制性”和並協觀念的“客譴和 儀器的原则同格” 的諭調, 正是和這程形而上學

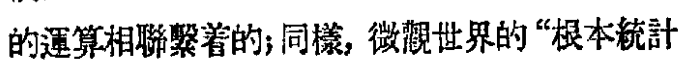
性”的論調则歸結到好像統計力學支配着倜别電 子的運動。

從道篇論文所討論的問題的觀點來看, 量子 力學中的, 由外國的已故的郎之萬所開始建立的, 而在䰻聯是以 K. B. 尼考耳斯基、 A. И. 布洛欣 采夫以及其他研究者第代表的學派, 把現代量子

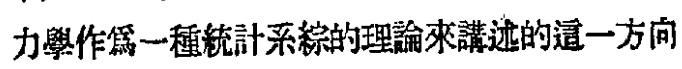
是具有重大意羕的。

㯰一個理諭第量子力篹提供了一個根本的基

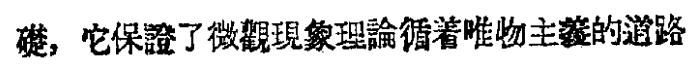

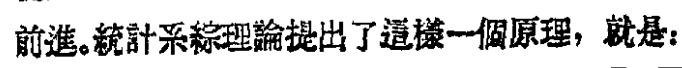

(1) 考瓦維洛夫: “光學研究所的襄道路”。 “物理科學的淮晨”，第16管，第7期(1936年)，892-894而。

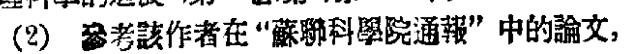
第 66 突,第 2 號(1949年), 185 -186面。

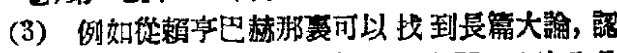

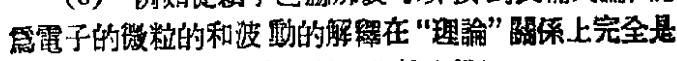

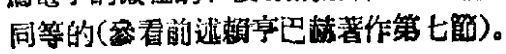
第入期
科學通啹 
現代量子力舆的結構不是建立在㑑別過程的理論 基磼上，而是徒㨜和經典統計力學不同的量子統

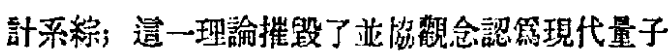

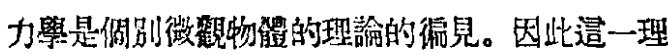

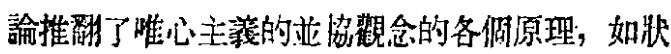

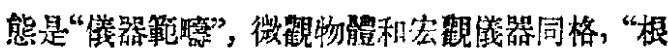

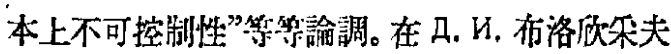
的“量子力學基礎”一書中，就是從浔個理論的䒨 點來講述量子力學的。

系綜理論在指出現代量子力學的發展方向 時, 並提壮一個建立關於個别過程的理論的任弱。 A. И. 布洛欣策夫在上述的書裹察道: “以後可能 發現我們目前無從猜想到的物理現象，可能根接

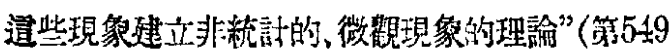
页)。但在 K. B. 尼古里斯基 (参看他的 “量子過 程”一書, 1940年版)，以及工. K. 布洛欣采夫的關 於系絲理論的叙迅中都汥有展䦐這個問題, 而這 就使微觀力學還停頃在斗路上。

例如當 Д. И. 布洛欣采夫這㧺竄道: “……测 不準關係適用於一莘微粒的系綜, 但不適用於單

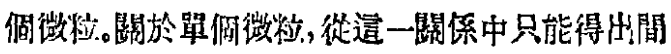
接的結諭”( 第64面)，我們促不能不同意他的見 解。

布洛欣采夫同時提壮㯰倜結論; “造就是，可

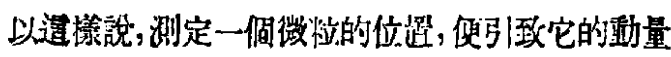
的改變, 這程改變由量子力學統計地猔示代來。造

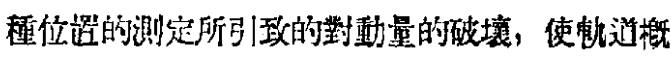
念不能應用到微憼䍀子_.”(同页)。

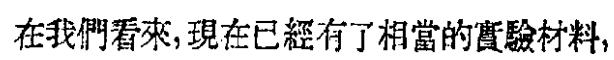
可以建立一储微観現象的非統計理諭了。五. и. 布 洛欣采夫及其他蕉聯物理祭家已經在着手建立造

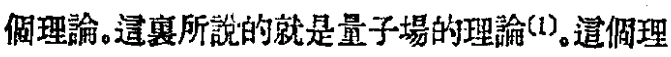

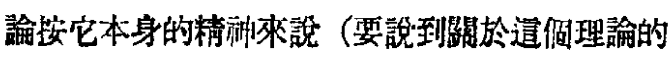
积达中的某些具娟的缺點現在還太早，因第造一 理諭還正在建立中），必須以同時承認物犋的場

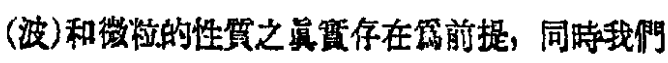
應裳認第它將要渻除隨着系綵理論（現代量子力 燢) 而來的一些矛盾们混淆的地方。

把與建立量子場理諭相關聯的一些問题放在

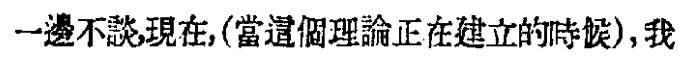
倗已敉不能不注意到, 從現代量子力學中一一在 系綜理諭中一一可以看出建立䍚嵄的一個理諭的
道正可能性。例如，像 A.И. 布洛欣采夫所指H的

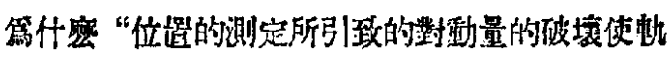

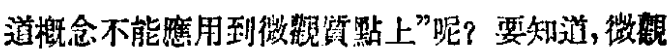

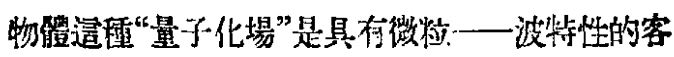
體。因此，軦道既念数它們自然是不能適用的，而

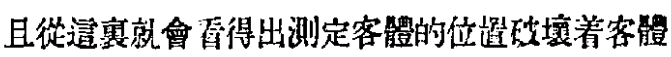
的動量，以及其他等䇣。

再則, 系線理論對波動亟數的物理意義問題， 是不是徽底解决了㖋? 系綜理論粉碎了把波動函

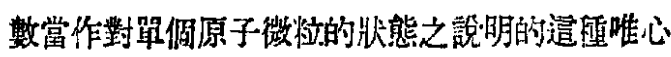
主義的理解。波動函數表現着量子梳計系称的特 徵，所以它是客観的說明，而不是上面說到過的所 謂䉝器的說明。然而系綜理論中的波動函數是作

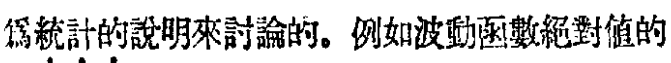
平方 $(\varphi)^{2}$ 是表示可以找到粒子坐標的幾率。任势 在於把波動函數由本質上的數學概念——它就是 以此出現於現代量子力學中一一變成第物 理摡

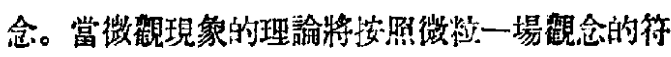
號形成洔，這一點將是可以做到的。

系棕理論的全部內容引向道一任務, 道也就 是它對於微觀現象理諭的墢展之進步意㼁。而並 協原理的全部內容却排斥提出造一任務, 因此它 從來沼有促進而且也不可能促進微䂓 現象理論 一包括量子力㜄在丙一的發展。

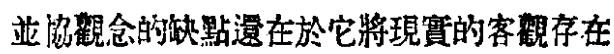

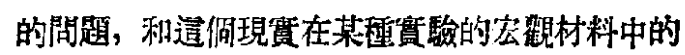
表現問題混第一談。

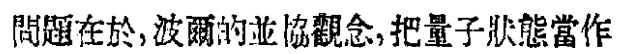
第這佯快態在宏觀溉念中的（從篦器得到的）表 現。带有波爾的䕱些的物理學家就會把测量電子 坐標的場合, 和测量笔子斩量的場合, 看作是不同 的。在第一保場合的現䁈，似乎和第二佪場合的現 叟是不同的。

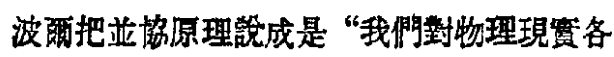

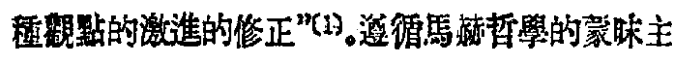

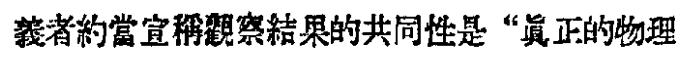

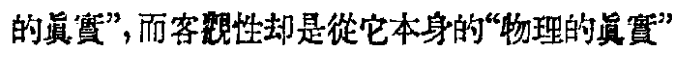
派生出來的摡念，他把“亚烧性的創立”看作是“從

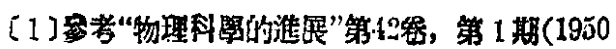

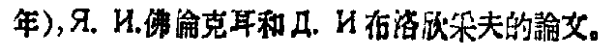


現代量子力學中結晶出來的、哲興上最重大的事 件”, 道不是偶然的。

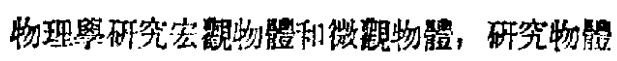

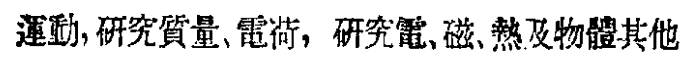
的性質——研究所有我們程之的非生物自然界的 東西，和構成其他更複椎的。更發涬的物質形代之 存在條件的東西。这储非生物自然界, 與生物自然 界以及人類江會一菉, 都是客觀地不低賴意識预

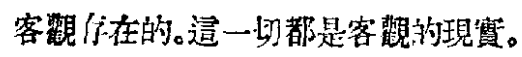

每一侗時代的新事實的發現，如地圆和地球 燒太陽運動的發現，或時間和空間量之不可分的

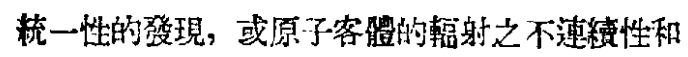
波動性的發現等等，都要求對某些鹤有的物理旣 念加以根本修正, 而以道合於道些新設現的新覾 念來替代它，但却不是重新修正那一佟倠物主義 的基本原理, 即: 客觀現賽是不位赖於物理學家而

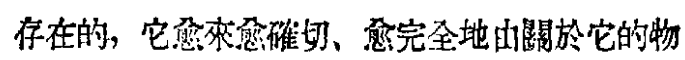
理覞念反胅出來。

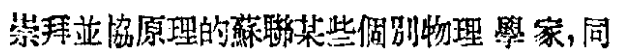
時也在遗一栕或那一栕形式中接受了波颇的“物

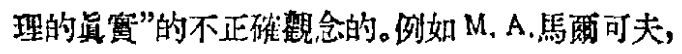

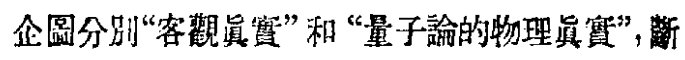
定後者是“微鹳世界真筫所表現的宏觀形式”，是

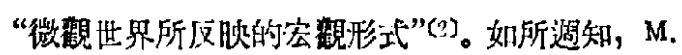

A. 馬爾可夫的論文已在蘇聯刊物中受到了公正 的批产平。B. A. 福克院士也同栐地在他第愛因斯 坦與波爾之間的討論所作的序言裹(3)，無批判地

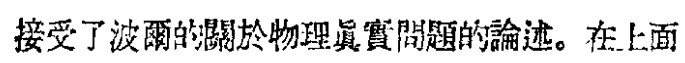

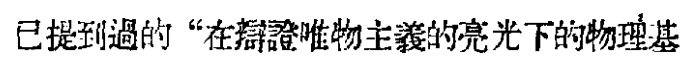

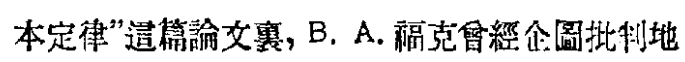

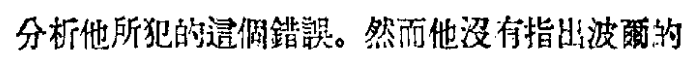
對物理真賽的理解是起源於並㳎原理的。對波酸

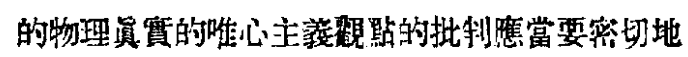

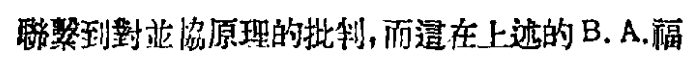
克論文中却佣好浔有。

上面所說的一切，和镍器在量子力學中的所

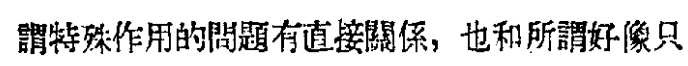
有用經典物理的觀念才可以洞察原子現解领域的 問題有直接關䋆。

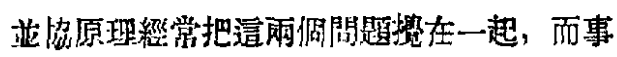

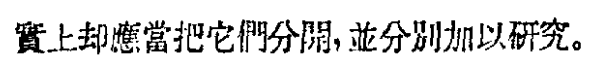

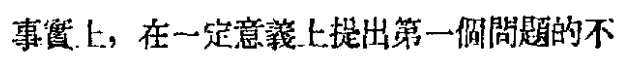

，單單只是量子力粫。從下面的推理就可以谽明造

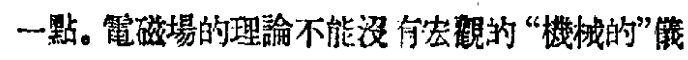

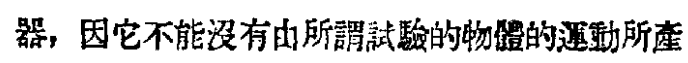
生的數摱。相對論在某些意議上，也是不能汥有 “經典的”僮器。踓然它䍌空間和洔間是從其不可

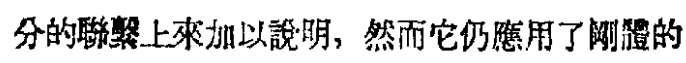
尺和鐘。同時, 不用任何經典力學的參考;相對諭

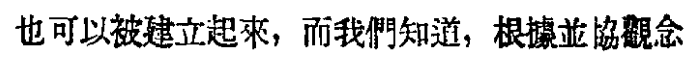

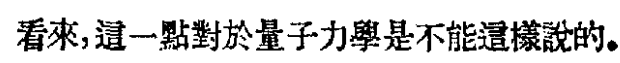

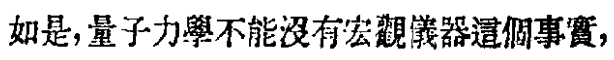
蓝不使造做理論和别的物理理䃋有所區别。踓然

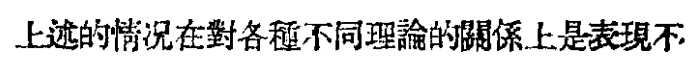
同的。

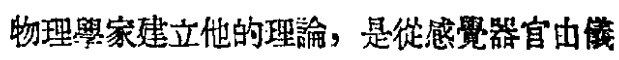

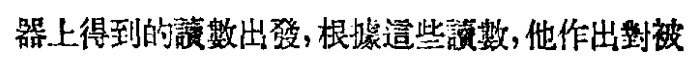

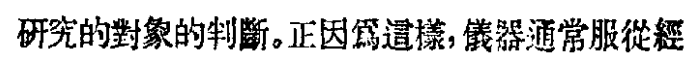

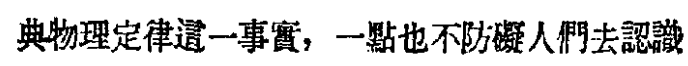
不包括在柾典物理中的現象, 犁定出符合於它椚 的本性的概念。

由於某些有足够佟件的根蛾，也可以把人看

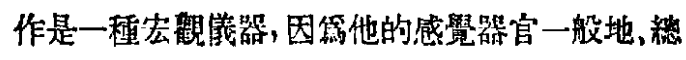

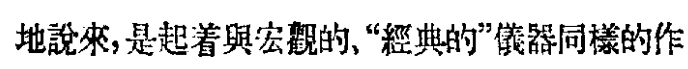

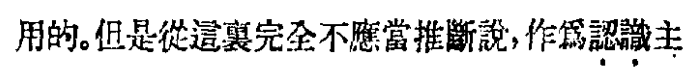
體的人, 可以像 M. A. 馬爾可夫所做的那㤬把他 看作是空觀簐器。

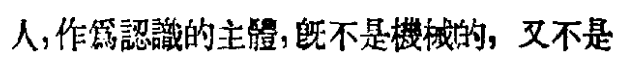

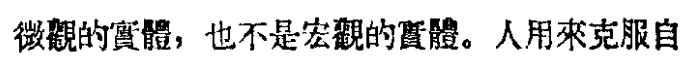
已的感學器官的局限性的義器, “外表上”在人看 來是宏数地或甚至是機栈地作用着。然而這一事 實並不表示人就一定要把所有一切東西都盗上

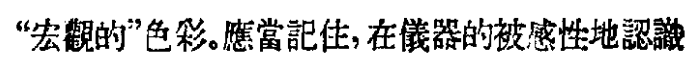
的可落整與测量的真正結果之間, 必須伱在着一 個被雜的理論過程, 只有在這犁條件下才能够特 在儀器上觀察到的現像的简單指连變成第對於不

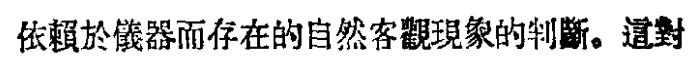
於由人類利用䪪器來研究的一切物理現象（包括 微粯現像在內)都是適用的。

(1)“物理科學的進展”第16管，期(1930年)， 第457而。

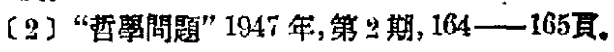

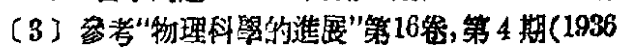
年), 436 - 440 頁。
第入期
科學通報

- $531 \cdot$ 
只有唯心主童者，如程素、加拿普或爱丁頓之 流，才認篇在電學理諭中研究的不是䉓場强度或 電勢，而是力和功，或甚至只是筆流計的指針偏轉 多少及驗電器的金篗張開多少 (1)。不利用力的㯕 念, 就不能確定䉓場强度, 但是場亚不等於力。同 禂, 不用動量或坐標, 就不能確定量子力學中的狀 態, 但是這個牀態亚不是“經典的”量, 正如 A.A. 严歴山大洛夫所令人信服地說過的那漛(

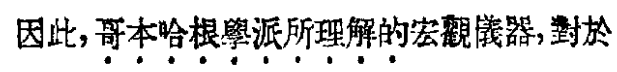
具有崅正內容的量子力學的建立, 是根本不重要

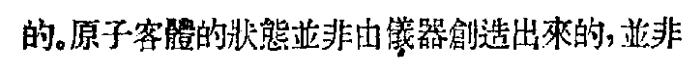

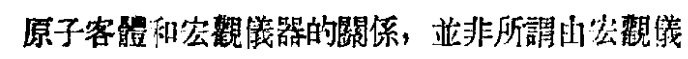
器得出的 “關於奘態的知識的記錄”; 微憼客體的

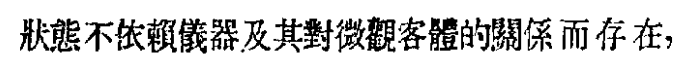
但它在逜整關係中影現出來, 通過這一程或那一 種低存於公觀䉝器之“經典”量而得到表示。

關於䉝器的作用問題就是這樣。

現在要問: 如果量子力舉不按照波爾的亚協

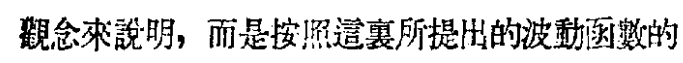
解釋來說明, 不是按恩原子客顝和空觀儀器闰格 的觀念來說明，而是按照原子客能的波一微粒特

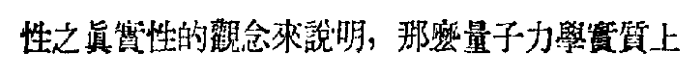
是否還需要經典力學作篇基礎呢?

由、上面所进程種而引出的道個閣題答娼, 大 栺上是很明白的。但是，自然這個問題還是應當特 别地、具體地來加以分析。不過毫㶵筑問, 量子力 學的界正內容和亚協筧念是浔有任何共同之點 的, 僄一觀念把留於䉝器在物理學中的作用問題

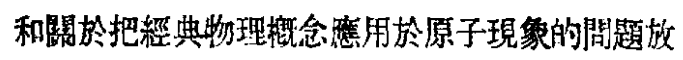
在首要的地位。和量子力學(也指任何其他物理理

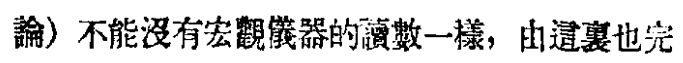
全不能得出結論語量子力學必定要以經典概念篇 基礎。

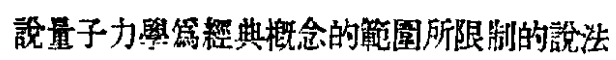
是錯鿁的; 闹栐，說量子力學只是規定释典微特的 或波的慨念㤰用於微觀現象的界限的說法也是錯 誤的。假如量了力學不是具你這檬一些新的慨念, 如由波動函敖說明的原子客晅的炏態，又如被拿

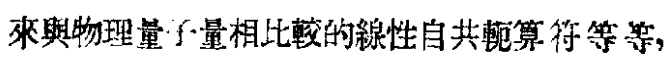
它就不能像它現在這樣了, 即不能反映微稫客體 的波一微煜本質了。至於量子力學新概念的物理 意洋的發現過程還沒有完成, 以及現代量子力學

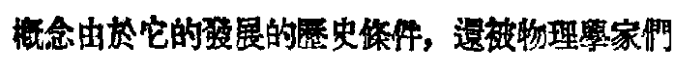
在“經典的”、宏筧的方式上速解釋，這却是另一回 事。微觀現象的理論的繼縜發展將會克服現代量 子力祭的不完整性(例如它的統計性)。

聯熬到儀器在量子力學中的“特別”作用的問 題,我們應當提一提 9. B. 史波里斯基在他“原子 物理”一書中的一些說法。一方面著者完全正不倠地 認第電子按其本監來說是沼有經典的胀態特性的 客體。而另一方面他舄道: “......嚾管如此，我們 却力圖用經典力學的辿語來措述篦子的行動”, 因 窟客觀過程在空間和時閒中進行的問題, “䴣根結 底, 我們逼是利用宏觀物體的籍器來碓定。( 然一, 426 頁。着重點是我加的一 $M \cdot$ 奥)。於是， 3 . B. 史波里斯基總結說: “不用說, 所研究的微觀 粘子的行動, 必須在這榚的空間時間計算系統中 來描述它們，這系梳使用經典力學概念，而且藉此 我們描述我們的宏觀的佈邆”(同上)。按习. B. 史 波里斯基的意兒，测不準關係正表示着經典描述 的礁用限度。

所以根據 3. B. 史波里斯基的意見，利用乘 典概念乃是量子力學的特點, 並且這種利用的必 要性又内儀器体身是宏觀系統這一事望所次定。

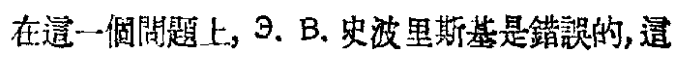
從上面所說的關於儀器在量子力學中的作用就可 以明白看到。同時還必須着重指出, 他認第量子

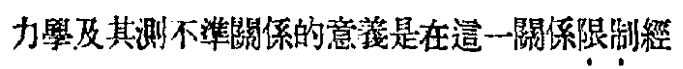
典力學摡念對错觀粒子的適用性, 而且僅此而已。 Э. B. 史波里斯基沒有更向前走, 因而他在事惯

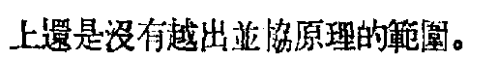

繁於對波丽的亚協原理的批判，問題就是道 檬。

䛾我們回到量子力學中的統計䦓題的結諭。 現代量子理論是統計的理論。意思就是說: 造一理 諭的原理, 既能適用於對很多同類原子客體的赛 驗, 又能適用於對一個原子客體重複賽驗的總和。 要是根搌這種觀點, 那末經典力學也應該稱焉統 計的理諭，因焦它的原理可以看作是適用於對同

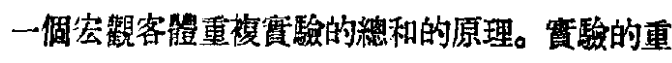
複是午何物理理論的必要前提。

然而, 正如 Л. H. 曼提里什坦院士所强調過

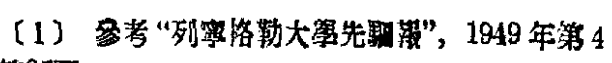
號，第67頁。 


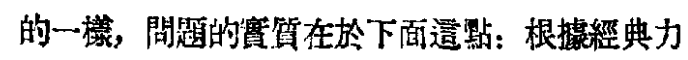
學, 任意狄小的分割對於所有一切被研究的數量 都是可能的; 量子力學否定後者。因此, 經典力學 和量子力學的美別, 不在於通些理諭的一個是統 計的, 另一個則不是, 茩则是在於統計的類型。

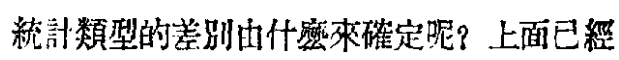
表明過了的, 就是由宏觀物體和微憼物體的差别

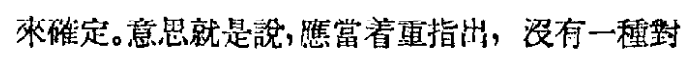

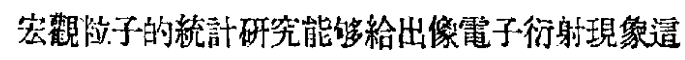
樣的特性。

㫫協觀念的形而上學和唯心主義在於它宣稱

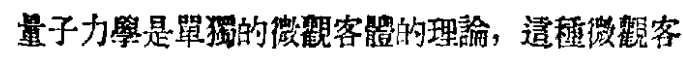
體被看作是與一個行動服從於波動的幾率定律之 粒子鲁同的東西; 亚在㓋它以微粒力學的概念來

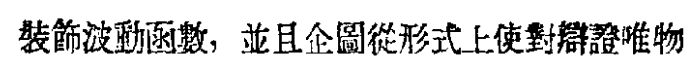

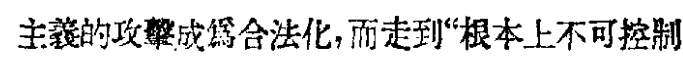

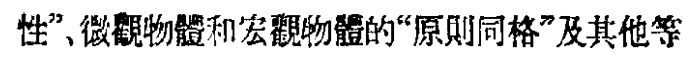
等。

简而言之，蓝協萑念在量子力學中地来了把

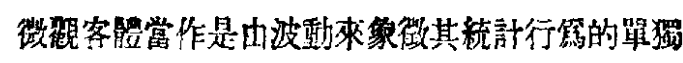

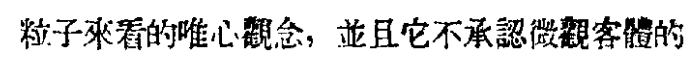
實際存在及其實在的徽粒，一波或徽粒，一場的特 性。

有些個别的正確地批制了波的的首協観念的 作者們却往往浔有把後一種情形也考虑到。K,B. 尼古里斯基便是習些作者中的一個'。

在我看來，即便在A.H.布洛欣朵夫的“量子力 學基礎”一書中,對於微觀現象的微煜一波本質的

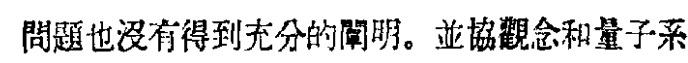
紜理諭間所存在的桹本區別在於: 根㨜前一種觀
念，量子力學的大多數論所有着梳計特性的原因， 是由测量所引起的客體狀態的根本上不可控制的 破懐; 而根據系綜理諭，現代量子力學自始就是和 量子梳計系綜有關的。但是, 問題又發生了: 組成 量子統計系棕的客體其本質究筧是怎核的? 單獨 的微観客顝的行動又是怎樣的呢? 並協觀念根㨜 它的唯心主義立場，使微觀現象的理諭離阇了正 確解沈閣題的途徑, 而引同唯心主義的泥沼中去。 系綜理論是導向這個解决的, 因篇它認定微篗客 顝的特性是在實驗所證明的系称特性中得到反 槛。但是采称理論, 不能解氿這個問題, 况且它是 通過微彷概念來反凌微觀現像的。這個問題的正 確解决，可以推测，将由現在物理學家們正在建立

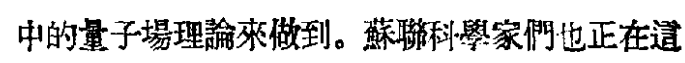
一個方向上研究渚微唯現貌们理諭。

用馬克思列蜜主義武裝起來的蘇称科學家們

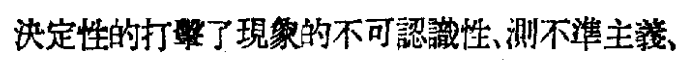
宇宙有限“理論”的唯心主義觀念以及其他反科 學的意見。他㑚有著一切佟件, 來在這樣的方向 上發展量子力學及其他現代物理理論, 就是使物 理理論正碓地、唯物地解釋在自然界發生的各現 象和過程, 使在造些理論中浔有唯心主義的虚構, 也就是說, 使通些理諭建立在唯一的科學的字宙 舅一一誩登唯物主䔉的基礎上。

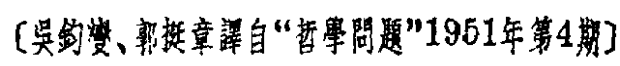

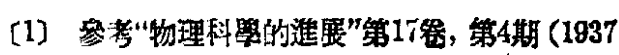
年), 第560頁。 